\title{
Review Article \\ Overview of the Role of Vanillin on Redox Status and Cancer Development
}

\author{
Daniel Pereira Bezerra, ${ }^{1}$ Anne Karine Nascimento Soares, ${ }^{2}$ \\ and Damião Pergentino de Sousa ${ }^{2}$ \\ ${ }^{1}$ Gonçalo Moniz Institute, Oswaldo Cruz Foundation (IGM-FIOCRUZ-BA), Salvador, BA, Brazil \\ ${ }^{2}$ Department of Pharmaceutical Sciences, Universidade Federal da Paraíba, 58051-970 João Pessoa, PB, Brazil \\ Correspondence should be addressed to Damião Pergentino de Sousa; damiao_desousa@yahoo.com.br
}

Received 17 September 2016; Revised 4 November 2016; Accepted 21 November 2016

Academic Editor: Kum Kum Khanna

Copyright (C) 2016 Daniel Pereira Bezerra et al. This is an open access article distributed under the Creative Commons Attribution License, which permits unrestricted use, distribution, and reproduction in any medium, provided the original work is properly cited.

\begin{abstract}
Bioactive natural products play critical roles in modern drug development, especially anticancer agents. It has been widely reported that various pharmacological activities of such compounds are related to their antioxidant properties. Vanillin is a natural substance widely found in many plant species and often used in beverages, foods, cosmetics, and pharmaceutical products. Antioxidant and anticancer potential have been described for this compound. Considering the importance of vanillin in the area of human health and food and pharmaceuticals sectors, in this review, we discuss the role of vanillin on redox status and its potential contribution to the prevention and the treatment of cancer.
\end{abstract}

\section{Introduction}

A great body of in vivo evidence supports the view that oxidative stress and the accompanying reactive oxygen species (ROS) are genotoxic and contribute to the development of cancers. Pathological processes mediated by oxidative stress include cell membrane leakage, mitochondrial dysfunction, glutathione depletion, and disturbed redox cell state and depletion of ATP. These processes affect the cells and DNA, resulting in tumors, inflammatory diseases, and various other health problems. Oxidative stress is implicated in numerous diseases and results in shorter life, hampered well-being and increasing public health spending [1]. Antioxidant therapies implementation requires a better understanding of free radical toxicity, its molecular mechanisms, and its involvement in disease.

Natural bioactive products play critical roles in anticancer drug development. In fact, natural molecules with antitumor activity reveal excellent pharmacotherapeutic potential [25]. Antioxidant activity is commonly found in many of these molecules, especially the phenolic substances $[6,7]$. Considering the involvement of reactive species as a source of various types of cancer, diets and/or drug therapies involving bioactive substances with antioxidant activity may well represent a preventive treatment approach to maintain the well-being of the patient. Some of these natural substances are present in various pharmaceutical, nutritional, and cosmetic products. For example, vanillin (Figure 1), a plant secondary metabolite and the main constituent of vanilla, is a phenolic phenylpropane $\mathrm{C}_{6}-\mathrm{C}_{1}$ carbonic structure derivative. It acts as an important flavor and aromatic component used worldwide. Vanillin is found in several essential plant oils, principally Vanilla planifolia, Vanilla tahitensis, and Vanilla pompona [8]; it is often found in processed foods, beverages, and pharmaceutical products and also in perfumery $[9,10]$. Vanillin has antioxidant and antitumor potential [11], and it is reported that its activity might be more beneficial for daily health care than had been previously thought [12]. A rich diet in such radical scavengers could reduce free radical cancer promotion [13]. Given the data on vanillin and considering its importance in its various applications and pharmacological properties, we discuss the role of vanillin on redox status and its potential contribution to cancer development and treatment. 


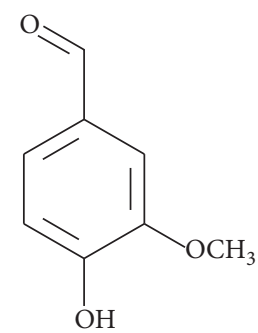

Figure 1: Chemical structure of vanillin (4-hydroxy-3-methoxybenzaldehyde).

\section{Methodology}

Searches were performed in the scientific literature databases: PubMed and Web of Science through June 2016 using the following key words: vanillin, antitumor, anticancer, oxidant and/or antioxidant.

\section{Antioxidant and Prooxidant Effects}

It is well known that neither $\mathrm{O}_{2}{ }^{--}$nor $\mathrm{H}_{2} \mathrm{O}_{2}$ is capable of interacting with either deoxyribose or the base portions of DNA; this suggests that the secondarily derived ${ }^{\circ} \mathrm{OH}$ radical may be the primary reactive species. Once generated, ${ }^{\circ} \mathrm{OH}$ may interact with DNA to produce at least 20 different DNA oxidation products [14]. The idea that a major risk factor for cancer is mitogenesis has also been proposed. It has long been appreciated that dividing cells are at an increased risk for developing mutations as compared to quiescent cells [15]. Oxidants produced by inflammatory leukocytes may induce mutagenesis and possibly carcinogenesis by promoting mitogenesis and by modifying DNA bases [16]. There is an increasing interest in oxygen-containing free radicals in biological systems because of their perceived roles as causative agents in the etiology of a variety of chronic disorders. Many natural products having antioxidant activities show protective biochemical functions and such metabolites have become subjects of great interest. A better understanding of the mechanisms of oxidative biological reactions (and their inhibition) should help to understand and treat or prevent various diseases, such as cancer.

In regard of the antioxidant effect of vanillin, some mixed results have been reported. Vanillin had weak superoxide anion scavenging activity ( $\mathrm{IC}_{50}$ of $2,945 \pm 247 \mu \mathrm{M}$ ) and exhibited no or little antioxidant activity against lipid peroxidation in mouse liver microsomes (inactive at 3,285 $\mu \mathrm{M}$ ) [17], 1,1-diphenyl-picrylhydrazyl (DPPH) radical scavenging assay $\left(\mathrm{IC}_{50}\right.$ value higher than $\left.100 \mu \mathrm{M}\right)$ [18], $\beta$-carotene decolorization assay [19], and linoleic acid and cholesterol oxidation assays [20]. On the other hand, vanillin at $2.5 \mathrm{mM}$ inhibited protein oxidation and lipid peroxidation induced by photosensitization with methylene blue plus light in rat liver mitochondria [21]. It also exhibited hydroxyl radical [22] and $2,2^{\prime}$-azinobis (3-ethylbenzothiazoline-6-sulfonic acid) radical cation $\left(\mathrm{ABTS}^{\circ+}\right)\left(\mathrm{IC}_{50}\right.$ value of $\left.16.25 \mu \mathrm{M}\right)$ [23] scavenging activities.
Furthermore, Tai et al. [12] assessed the antioxidant effect of vanillin using multiple antioxidant assays. Vanillin showed potent antioxidant activity in the $\mathrm{ABTS}^{\circ+}$ scavenging assay, in the oxygen radical absorbance capacity (ORAC) assay, and in the oxidative hemolysis inhibition assay (OxHLIA), but showed no activity in the DPPH radical and galvinoxyl radical scavenging assays. Its antioxidant mechanism is via self-dimerization. The dimerization contributed to the high reaction stoichiometry against $\mathrm{ABTS}^{\circ+}$ and 2,2'-azobis(2methylpropionamidine) dihydrochloride- (AAPH-) derived radicals to result in the strong antioxidant effect of vanillin [12]. Pretreatment of vanillin $(100 \mathrm{nM})$ also reduced rotenone induced mitochondrial dysfunction, oxidative stress, and apoptosis in SH-SY5Y neuroblastoma cells [24]. These data reinforce that vanillin presents interesting antioxidant properties, which is dependent on the method used.

In in vivo antioxidant assay, mice were orally given a single dose $(100 \mathrm{mg} / \mathrm{kg})$ of vanillin. The highest activity in the plasma ORAC assay was observed at $5 \mathrm{~min}$, when the concentrations of vanillin, vanillic acid, and protocatechuic acid were high [12]. Moreover, pretreatment with vanillin $(150 \mathrm{mg} / \mathrm{kg})$ presented hepatoprotective effect against carbon tetrachloride-induced hepatotoxicity by the inhibition of protein and lipid oxidation processes, the increase in antioxidant enzymes activities, and the inhibition of inflammation mediators [25]. More recently, Ben Saad et al. [26] demonstrated the protective effects of vanillin against potassium bromate- $\left(\mathrm{KBrO}_{3}^{-}\right)$induced oxidative stress. The treatment with vanillin ( $100 \mathrm{mg} / \mathrm{kg} /$ day for 15 days) reduced histopathological changes in $\mathrm{KBrO}_{3}$-induced kidney and decreased renal oxidative damage by inhibiting ROS generation and reversing antioxidant enzyme activities in kidney [26]. These effects may be results of interactions between vanillin and cellular proteins or signaling pathways.

In relation of the prooxidant effect of vanillin, Castor et al. [27] have reported that vanillin can has prooxidant action when its transient free radicals are generated intracellularly. Transient free radicals from vanillin were generated by horseradish peroxidase/hydrogen peroxide-mediated oxidation and their prooxidant effects were assessed using cysteine, glutathione, ovalbumin, and the coenzyme NADPH as target biomolecules. Vanillin, at concentration of $10 \mu \mathrm{M}$, promoted oxidation of glutathione, sulfhydryl groups, and NADPH at experimental conditions [27]. This prooxidant activity can explain its cytotoxic action in some tumor cell lines. Briefly, we believe that both antioxidant and prooxidant characteristics of vanillin contribute to its benefits and deleterious effects. The antioxidant activity of vanillin seems to be related to its antimutagenic and anticarcinogenic activities. In contrast, the prooxidant effects of vanillin radicals can be related to its anti-invasive, antimetastatic, antiangiogenic, and cytotoxic activities.

The antioxidant activity of phenolic substances has been reported for several natural substances structurally similar to vanillin. The hydroxyl of the aromatic ring plays an important role in the antioxidant activity via the homolytic fragmentation of the O-H bond $[28,29]$. It has been reported that vanillin exhibited hydroxyl radical [30] and 2,2' -azinobis (3-ethylbenzothiazoline-6-sulfonic acid) radical cation $\left(\mathrm{ABTS}^{\circ+}\right)$ 
[23] scavenging activities. Its antioxidant activity can be attributed to the presence of hydroxyl group $\left(\mathrm{OH}^{*}\right)$ linked to aromatic ring. Therefore, substances having the phenol functional group may also have antioxidant activity, as exhibited by vanillin.

\section{Antimutagenic Activity}

Mutagenic agents are involved in genotoxicity and carcinogenesis processes and as well in the inception and pathogenesis of several chronic degenerative diseases. Antimutagenic agents are the compounds that have protective effects against mutagenics, which include "desmutagens" that cause chemical and biochemical mutagen modifications before DNA damage and "bioantimutagens" that reduce the mutation process after DNA damage [31]. Vanillin has been classified as a bioantimutagen and is able to inhibit mutagenesis induced by chemical and physical mutagens in various cell systems.

The antimutagenic effect of vanillin was first tested on bacteria [32]. Vanillin (at concentration of $150 \mu \mathrm{g} / \mathrm{mL}$ $[\sim 986 \mu \mathrm{M}])$ inhibits mutagenesis induced by 4 -nitroquinoline 1-oxide (4-NQO), furylfuramide (AF-2), captan, or methylglyoxal in Escherichia coli WP2s. In studies using repair enzymes in deficient strains, it was suggested that vanillin increased DNA damage repair through the recombinational repair pathway [32-34]. Vanillin was not effective against mutations provoked by 3 -amino-l-methyl- $5 \mathrm{H}$-pyrido[ $[4,3-b]$ indole (Trp-P-2) or 2-amino-3-methylimidazo[4,5-f] quinoline (IQ) in Salmonella typhimurium TA98 [32], yet it reduced the frequency of spontaneous mutations in S. typhimurium TA102 and TA104, reducing mutations at GC sites, but not AT sites, and such antimutagenic effect was dependent on the presence of the pKM101 plasmid in homologues of TA104 $[35,36]$. Vanillin was also effective against spontaneous mutation in the wild-type strain NR9102 of E. coli, and this effect was independent of both the SOS and NER pathways. Moreover, vanillin causes certain types of DNA damage, which elicit recombinational repair. This recombinational repair activation permits vanillin-induced damage repair and also that of other DNA lesions, thus reducing the frequency of spontaneous mutation [37].

The antimutagenic effect of vanillin has also been studied in Drosophila melanogaster. In the germ cell line of D. melanogaster, vanillin decreased both spontaneous and mitomycin C- (MMC-) induced ring X-loss but had no effect on the mutagenic activity of methyl methanesulfonate (MMS) [38]. On the other hand, vanillin weakly inhibited mutations induced by MMC but increased recombination in MMCtreated lesions in D. melanogaster somatic cells [39]. Posttreatment with vanillin produced a synergistic effect on recombination in D. melanogaster somatic cells with either ethyl methanesulfonate (EMS) or bleomycin [40]. However, the effects of cotreatment with vanillin led to significant protection against the general genotoxicity of EMS, $N$-ethyl$\mathrm{N}$-nitrosourea (ENU), $\mathrm{N}$-methyl- $\mathrm{N}$-nitrosourea (MNU), and bleomycin [41]. Using the DNA repair test for $D$. melanogaster, [42] reported the effects of vanillin on the repair of lethal damage produced by $N$-ethyl- $N$-nitrosourea
(ENU), ethyl methanesulfonate (EMS), and MMC. Vanillin also increased the toxicity of MMC and EMS in repairdeficient flies. Yet, it protected against the lethality of ENU in repair-defective flies. This complex antimutagenic effect has been attributed to vanillin caused inhibitory activity against oxidative damage and stimulatory action on detoxification enzymes [41, 42].

Contradictory results were also found in studies using mammalian cells. In studies performed in Chinese hamster ovary fibroblast $\mathrm{CHO} \mathrm{K}-1$ cells, vanillin was able to promote an increase in the frequencies of sister-chromatid exchanges (SCE) in $N$-ethyl- $N^{\prime}$-nitro- $N$-nitrosguanidine- (ENNG-), MMC-, EMS-, ENU-, and MNU-treated cells, but not $N$-methyl- $N$-nitrosoguanidine- (MNNG-) or MMS-treated cells. The effect was S-phase-dependent in MMC-treated cells $[43,44]$. In contrast, the frequency of chromosome aberrations was significantly decreased in MMC-treated cells in phase $G_{2}$, by posttreatment with vanillin [44]. In addition, vanillin-treatment in the $G_{1}$ phase suppressed $\mathrm{X}$-ray-induced breakage-type and exchange-type chromosome aberrations. Treatment with vanillin in phase $G_{2}$ suppressed ultraviolet light (UV) and X-ray-induced breakage types, but not exchange-type chromosome aberrations [45]. In experiments performed in Chinese hamster lung fibroblast V79 cells, vanillin reduced the frequencies of 6-thioguanine-resistant mutations induced by UV, X-ray, and ENU [46]. The cytotoxicity and chromosomal aberrations induced by hydrogen peroxide $\left(\mathrm{H}_{2} \mathrm{O}_{2}\right)$ were suppressed when V79 cells were posttreated with vanillin. However, vanillin increased EMSinduced toxicity [47]. Vanillin also reduces methotrexate-, $\mathrm{X}$-ray- and UV-induced micronucleated and binucleated aberrant cells $[48,49]$.

The in vivo antimutagenic effects of vanillin were studied in X-ray- and MMC-induced micronuclei in mouse bone marrow cells. Posttreatment with vanillin caused decreases in the frequency of X-ray- and MMC-induced micronucleated polychromatic erythrocytes [50,51]. Vanillin was also investigated in the mouse spot test using male PW and female C57BL/10 mice. Three successive oral administrations of vanillin at $500 \mathrm{mg} / \mathrm{kg}$ decreased the ENU-induced frequency of recessive carrier pups [46].

The ability of vanillin to inhibit photosensitizationinduced single-strand breaks (ssbs) in plasmid pBR322 DNA has been examined in a cell-free system, independent of DNA repair/replication processes. Vanillin was found to provide effective DNA protection against photosensitization-induced ssbs (mainly type II reaction) in the absence of DNA repair, replication machinery, or other cellular defenses, which can be in part due to its ability to scavenge $\mathrm{O}_{2}[23,52]$. On the other hand, vanillin was able to inhibit mutations at the CD59 locus in human-hamster hybrid $\mathrm{A}_{\mathrm{L}}$ cells induced by $\mathrm{H}_{2} \mathrm{O}_{2}$, MNNG, and MMC, but not ${ }^{137} \mathrm{Cs} \gamma$-radiation. The effects were attributed to the ability of vanillin to inhibit the DNA repair process that leads to the death of potential mutants or to enhancement of DNA repair pathways that protect against mutation but create lethal DNA lesions during the repair process [53]. In addition, vanillin is able to block DNA repair by nonhomologous DNA end-joining (NHEJ) and to selectively 
inhibit DNA-protein kinase (DNA-PK) activity in experiments using human lymphoma GM00558 cells and related gene deficient cells. Vanillin presented no detectable effects on other steps of the NHEJ process, on unrelated protein kinase, or on DNA mismatch repair in cell extracts. Vanillin also potentiated the cytotoxicity of cisplatin but did not affect sensitivity to UV [54].

The antimutagenic potential of vanillin was also assessed using both spontaneous and IQ-induced micronucleus frequencies in human hepatocellular carcinoma HepG2 cells. Vanillin caused a moderate increase in micronucleus numbers at the high concentration tested $(500 \mu \mathrm{g} / \mathrm{mL}[\sim 3,286 \mu \mathrm{M}])$; however, posttreatment of the cells with vanillin was able to inhibit IQ-induced micronuclei [55]. In addition, global gene expression in vanillin-treated mammalian cells was assessed against spontaneous mutagenesis in mismatch repair- (MMR-) deficient human colon cancer HCT116 cells. At concentrations of $0.5-2.5 \mathrm{mM}$, vanillin decreased the spontaneous mutant fraction. At concentrations (0.5$2.5 \mathrm{mM}$ ) that were antimutagenic in HCT116 cells, vanillin caused DNA damage in both mismatch repair-proficient $($ HCT116 + chr3) and deficient (HCT116) cells. A total of 64 genes presented the expression changed in vanillin- treatedHCT116 cells $(2.5 \mathrm{mM}$ for $4 \mathrm{~h}$ ), including genes related to oxidative damage, stress response, DNA damage, apoptosis, and cell growth, demonstrating that DNA damage contributes to vanillin's antimutagenic effect [56]. Moreover, vanillin $(100 \mu \mathrm{M})$ reduced UV-induced cytotoxicity and DNA damage in human keratinocyte stem cells. It also increased the production of proinflammatory cytokines and decreased the phosphorylation of ataxia telangiectasia mutated (ATM), tumor suppressor protein 53 (p53), c-Jun N-terminal kinase/ stress-activated protein kinase (JNK), serine threonine kinase checkpoint kinase 2 (Chk2), p38/mitogen-activated protein kinase (p38), S6 ribosomal protein (S6RP), and histone 2A family member X (H2A.X), suggesting that the ATM/p53 pathway is involved in the vanillin-induced mutagen protective mechanisms [57].

The protective effect of vanillin against $\mathrm{KBrO}_{3}$ induced liver, bone, and blood disorders has also been investigated $[58,59]$. Coadministration of vanillin to $\mathrm{KBrO}_{3}$-treated mice significantly prevented DNA damage, hepatic cell alteration, and plasma transaminases increases, inhibited hepatic lipid peroxidation, and attenuated depletion of enzymatic and nonenzymatic antioxidants and expression levels of proinflammatory cytokines, including tumor necrosis factor- $\alpha$, interleukin-1 $\beta$, interleukin-6, and COX2.

Although vanillin has shown comutagenic effects in some models, its antimutagenic effect (in concentration range in $\mu \mathrm{M}$ ) was extensively evaluated and appears to be due to its effects on cell redox and DNA repair pathways (Figure 2).

\section{Anti-Carcinogenic Activity}

Since vanillin presents antimutagenic effect in differing models and based on the close relationship between antimutagenic and anticarcinogenic activities, it was expected that vanillin presents anticarcinogenic effect; however, few studies

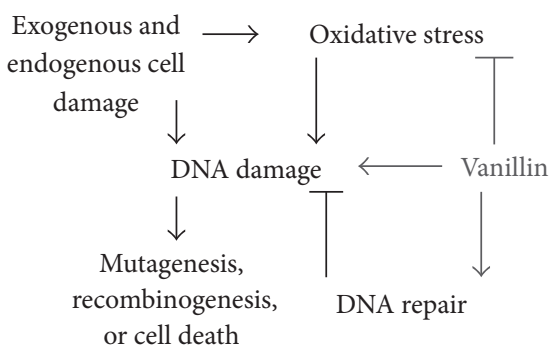

FIGURE 2: Overview of the antimutagenic effect of vanillin.

thus performed to investigate its anticarcinogenic effects have shown only contradictory results.

The anticarcinogenic effect of vanillin was first evaluated in the initiation stage of hepatocarcinogenesis using an animal model. In this model, the rats were given a diet containing $1 \%$ vanillin for 8 days. On day 7 , the animals received a single dose of the hepatocarcinogen, IQ, and $12 \mathrm{~h}$ afterwards, a twothird partial hepatectomy for initiation, and 2 weeks thereafter, they were placed on a promotion regimen comprising phenobarbital and a single dose of D-galactosamine. Within 11 weeks, antioxidant effect was assessed by comparing values for preneoplastic placental glutathione S-transferase positive $\left(\mathrm{GST}_{-} \mathrm{P}^{+}\right)$foci. Vanillin significantly decreased the number of GST-P ${ }^{+}$foci $/ \mathrm{cm}^{2}$, suggesting inhibitory effects on hepatocarcinogenesis initiation induced by the food carcinogen IQ [60].

Vanillin was also evaluated in a medium term multiorgan rat carcinogenesis model. Carcinogen-treated male F344 rats received vanillin in the diet at a dose of $1 \%$. Vanillin was administered from 1 day before and throughout the carcinogen exposure period or after completion of the initiation regimen. All surviving animals were sacrificed at the end of week 36. In this model, vanillin only weakly inhibited small intestine and lung carcinogenesis but significantly increased colon carcinogenesis in the initiation phase and also enhanced the development of stomach and renal lesions in the promotion phase [61].

Recently, the anticarcinogen or cocarcinogen effects of vanillin were studied in azoxymethane- (AOM-) induced aberrant crypt foci- (ACF-) bearing rats. AOM-challenged rats were treated with vanillin orally and intraperitoneally at low $(150 \mathrm{mg} / \mathrm{kg})$ and high $(300 \mathrm{mg} / \mathrm{kg})$ doses, and then ACF density, multiplicity, distribution, and gene expression were observed. Vanillin consumed orally had no effect on ACF; however, when administered through intraperitoneal injection at higher concentration vanillin was cocarcinogenic, which could well increase ACF density and multiplicity. The expression of colorectal cancer biomarkers, protooncogenes (beta-catenin $\uparrow$ and $\mathrm{FOS} \uparrow$ ), recombinational repair (XRCC2 $\uparrow$ ), mismatch repair (PMS2 $\uparrow$ ), cell cycle arrest (p21 and cyclin $\mathrm{B} \downarrow$ ), and tumor suppressor gene (tumor suppressor gene $\mathrm{p} 53 \uparrow)$ were also affected by vanillin $[62,63]$. The mixed anticarcinogenic/cocarcinogenic results found for vanillin suggest that other carcinogen models must be evaluated to better understand the role of vanillin on carcinogenesis. 


\section{Anti-Invasive, Antimetastatic, and Antiangiogenic Activities}

In cancer invasions, the key events of metastasis and angiogenesis are considered to be therapeutic targets for cancer prevention and treatment, and interestingly, vanillin presents anti-invasive, antimetastatic, and antiangiogenic activities in differing models.

In vitro studies reveal that vanillin, in noncytotoxic concentrations, inhibits invasion and migration of mouse mammary adenocarcinoma $4 \mathrm{~T} 1$ cells and inhibits the enzymatic activity of their metalloproteinase 9 (MMP-9) matrix secretions [64]. In addition, vanillin (also in noncytotoxic concentrations) reduces invasive capacity, suppresses $12-\mathrm{O}$ tetradecanoylphorbol-13-acetate- (TPA-) induced enzymatic activity of MMP-9, and decreases the mRNA level of MMP-9 induced in HepG2 cells, which occurs via downregulation of the NF- $\kappa \mathrm{B}$ signaling pathway [65]. In the range of noncytotoxic concentrations, vanillin also exhibits inhibitory effects on hepatocyte growth factor- (HGF-) induced migration of human lung A549 carcinoma cells, this due to inhibitory activity of phosphatidylinositol 3-kinase (PI3K). The effect has no correlation with the antioxidant activity of vanillin [66].

The in vivo antitumor, antimetastatic, and antiangiogenic effects of vanillin have also been investigated. The effect of vanillin on the growth and metastasis of $4 \mathrm{~T} 1$ cells was assessed in $\mathrm{BALB} / \mathrm{c}$ mice. In this model, the $4 \mathrm{~T} 1$ cells were injected into the mammary fat pad in female mice. Vanillin $(100 \mathrm{mg} / \mathrm{kg})$ was orally administrated 6 times per week for one month, starting on the first day after tumor implantation. Vanillintreated animals showed significantly reduced numbers of metastasized lung colonies as compared to the controls, without any inhibitory effect on primary tumor growth [64]. The in vivo antiangiogenic activity of vanillin was determined through inhibition of minor blood vessel formation (in chick chorioallantoic membrane; CAM assay) between day 3 and day 4 of chick embryo development. After exposure to vanillin for $24 \mathrm{~h}$, inhibition of the minor blood vessel formation in day 4 eggs in the areas under the agarose pellets was observed at dosage in the range 100-500 nmol/pellet egg [66]. Despite the promising results found for the anti-invasive, antimetastatic, and antiangiogenic activities of vanillin, the data are limited. Further studies must be performed in new models to better characterize the effects and molecular pathways of vanillin.

\section{Cytotoxic Activity}

Vanillin in high concentrations (mM range) has been described as a cytotoxic agent against many cell lines, including mouse fibroblast $3 \mathrm{~T} 3$ cells $[67,68]$, human ovarian carcinoma A2780-SC1 cells [54], human colorectal carcinoma HT-29 cells [68], HepG2 cells [69], human cervical carcinoma HeLa cells [70], and human colorectal carcinoma SW480 cells [71]. However, only a few studies investigated vanillin's cytotoxic mechanism of action.

The vanillin-treatment gene expression profile was evaluated [69] in HepG2 cells. Genes downregulated by vanillin were grouped into three gene ontological categories: regulation of cellular process, cell cycle, and death. Further, most of the downregulated genes were associated with cancer progression. Analysis of Fos-related transcription factor activator protein 1 (AP-1) showed that vanillin inhibits AP-1 activity, while diminishing the phosphorylation of extracellular signal-regulated protein kinase (ERK), thus indicating vanillin-regulated AP-1 activity via the ERK pathway. In other results [68], vanillin was able to induce both cytolytic and cytostatic effects in HT-29 cells. It also led to cell death through apoptosis pathways. Cell cycle analysis showed that vanillin induces $G_{0} / G_{1}$ arrest at lower concentrations $(200 \mu \mathrm{g} / \mathrm{mL}[\sim 1,315 \mu \mathrm{M}])$, while leading to $\mathrm{G}_{2} / \mathrm{M}$ arrest at higher concentrations $(1000 \mu \mathrm{g} / \mathrm{mL}[\sim 6,573 \mu \mathrm{M}])$. In addition, pretreatment of $\mathrm{HeLa}$ cells with vanillin enhanced tumor necrosis factor-related apoptosis-inducing ligand (TRAIL) induced cell death through inhibition of NF- $\kappa \mathrm{B}$ activation [70]. As cited above, the cytotoxic effect of vanillin is yet poorly reported, but based on the fact that it presents cytotoxicity only in high concentrations, its potential as a cytotoxic agent is low. The therapeutic potential of vanillin seems to be linked to its chemopreventive, anti-invasive, antimetastatic, and antiangiogenic actions (Table 1).

\section{Conclusion}

The studies presented in this review reveal vanillin's antioxidant activity, its antitumor action, and its therapeutic potential in cancer treatment and prevention. Consequently, the use of vegetables rich in this natural product might well be useful in inhibiting the free radicals responsible for tumor development. The data reported in this review are in accordance with the scientific understanding that a better quality of life and increased longevity may be obtained via healthy food, with the beneficial action of natural bioactive products.

\section{Abbreviations}

4-NQO: 4-Nitroquinoline 1-oxide

AAPH: $\quad 2,2^{\prime}$-Azobis(2-methylpropionamidine) dihydrochloride

$\mathrm{ABTS}^{\bullet+}$ : $\quad$ 2,2'-Azinobis(3-ethylbenzothiazoline-6-sulfonic acid) radical cátion

ACF: Aberrant crypt foci

AF-2: Furylfuramide

AOM: Azoxymethane

AP-1: Activator protein 1

ATM: Ataxia telangiectasia mutated

Chk2: $\quad$ Serine threonine kinase checkpoint kinase 2

DNA-PK: DNA-protein kinase

DPPH: 1,1-Diphenyl-picrylhydrazyl

EMS: $\quad$ Ethyl methanesulfonate

ENNG: $\quad N$-Ethyl- $N^{\prime}$-nitro- $N$-nitrosguanidine

ENU: $\quad N$-Ethyl- $N$-nitrosourea

ERK: Extracellular signal-regulated protein kinase 
TABLE 1: Summary of the main molecular targets of vanillin.

\begin{tabular}{|c|c|}
\hline Biological process & \\
\hline Cell proliferation and cell cycle & 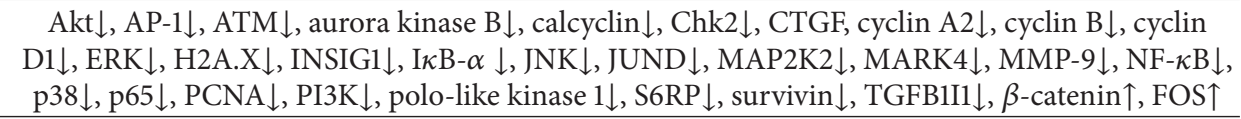 \\
\hline $\begin{array}{l}\text { DNA damage, oxidative, and stress } \\
\text { responses }\end{array}$ & $\begin{array}{c}\mathrm{CLK} 2 \uparrow, \mathrm{DDIT} 4 \uparrow, \mathrm{GCLC} \uparrow, \mathrm{GCLM} \uparrow, \mathrm{HMOX} 1 \uparrow, \mathrm{HSPA} 1 \mathrm{~B} \uparrow, \mathrm{PMS} 2 \uparrow, \mathrm{SLC} 7 \mathrm{~A} 11 \uparrow, \mathrm{TRIM} 16 \uparrow, \mathrm{UGP} 2 \uparrow, \\
\mathrm{XRCC} 2 \uparrow, \mathrm{DNA}-\mathrm{PK} \downarrow, \mathrm{DNMT} 3 \mathrm{~B} \downarrow, \mathrm{DUSP} 6 \downarrow, \mathrm{FGFR} 2 \downarrow, \mathrm{FZD} 2 \downarrow, \mathrm{NHEJ} \downarrow, \mathrm{PPP} 1 \mathrm{R} 10 \downarrow, \mathrm{SLC} 35 \mathrm{D} 2 \downarrow \\
\mathrm{UNG} 2 \downarrow\end{array}$ \\
\hline$x_{10} \mathrm{H}_{\mathrm{H}}$ & \\
\hline Invasion and metastasis & \\
\hline \multicolumn{2}{|c|}{$\begin{array}{l}\text { Akt, protein kinase B; AP-1, activator protein 1; ATM, ataxia telangiectasia mutated; Chk2, serine threonine kinase checkpoint kinase 2; CLK2, CDC-like } \\
\text { kinase 2; CTGF, connective tissue growth factor; DDIT4, damage-inducible transcript 4; DNA-PK, DNA-protein kinase; DNMT3B, DNA (cytosine-5-)- } \\
\text { methyltransferase } 3 \text { beta; DUSP6, dual specificity phosphatase 6; ERK, extracellular signal-regulated protein kinase; FGFR2, fibroblast growth factor receptor } \\
\text { 2; FZD2, frizzled homolog } 2 \text { (Drosophila); GCLC, glutamate-cysteine ligase, catalytic subunit; GCLM, glutamate-cysteine ligase, modifier subunit; H2A.X, } \\
\text { histone 2A family member X; HMOX1, heme oxygenase (decycling) 1; HSPA1B, heat shock 70 kDa protein 1B; INSIG1, insulin induced gene 1; I } \kappa \text { B- } \alpha \text {, nuclear } \\
\text { factor of kappa light polypeptide gene enhancer in B-cells inhibitor, alpha; JNK, c-jun N-terminal kinase/stress-activated protein kinase; JUND, jun D proto- } \\
\text { oncogene; MAP2K2, mitogen-activated protein kinase kinase 2; MARK4, MAP/microtubule affinity-regulating kinase 4; MMP-9, matrix metalloproteinase } \\
\text { 9; NF- } \kappa \text { B, factor nuclear kappa B; NHEJ, non-homologous DNA end-joining; p21, cyclin-dependent kinase inhibitor 1; p38, p38/mitogen-activated protein } \\
\text { kinase; p53, tumor suppressor protein 53; p65, transcription factor p65; PCNA, proliferating cell nuclear antigen; PI3K, phosphatidylinositol 3-kinase; PMS2, } \\
\text { mismatch repair endonuclease; PPP1R10, protein phosphatase 1, regulatory subunit 10; S6RP, S6 ribosomal protein; SLC35D2, solute carrier family 35, member } \\
\text { D2; SLC7A11, solute carrier family 7; TGFB1I1, transforming growth factor beta 1 induced transcript 1; TRIM16, tripartite motif-containing 16; UGP2, UDP- } \\
\text { glucose pyrophosphorylase 2; UNG2, uracil-DNA glycosylase 2; XRCC2, DNA repair protein. }\end{array}$} \\
\hline
\end{tabular}

\begin{tabular}{|c|c|}
\hline GST-P ${ }^{+}:$ & $\begin{array}{l}\text { Preneoplastic glutathione } \\
\text { S-transferase placental form-positive }\end{array}$ \\
\hline H2A.X: & Histone 2A family member $\mathrm{X}$ \\
\hline $\mathrm{H}_{2} \mathrm{O}_{2}$ : & Hydrogen peroxide \\
\hline HGF: & Hepatocyte growth factor \\
\hline IQ: & $\begin{array}{l}\text { 2-Amino-3-methylimidazo[ }[4,5 \text { - } \\
f] \text { quinoline }\end{array}$ \\
\hline JNK: & $\begin{array}{l}\text { c-Jun } \mathrm{N} \text {-terminal } \\
\text { kinase/stress-activated protein kinase }\end{array}$ \\
\hline MMC: & Mitomycin C \\
\hline MMP-9: & Matrix metalloproteinase 9 \\
\hline MMS: & Methyl methanesulfonate \\
\hline MNNG: & $N$-Methyl- $N$-nitrosoguanidine \\
\hline MNU: & $N$-Methyl-N-nitrosourea \\
\hline $\mathrm{NF}-\kappa \mathrm{B}:$ & Factor nuclear kappa B \\
\hline NHEJ: & Nonhomologous DNA end-joining \\
\hline ORAC: & Oxygen radical absorbance capacity \\
\hline OxHLIA: & Oxidative hemolysis inhibition assay \\
\hline p38: & p38/mitogen-activated protein kinase \\
\hline p53: & Tumor suppressor protein 53 \\
\hline potassium bromate: & $\mathrm{KBrO}_{3}$ \\
\hline PI3K: & Phosphatidylinositol 3-kinase \\
\hline S6RP: & S6 ribosomal protein \\
\hline SCE: & Sister-chromatid exchanges \\
\hline ssbs: & Single-strand breaks \\
\hline TPA: & 12-O-Tetradecanoylphorbol-13-acetate \\
\hline TRAIL: & $\begin{array}{l}\text { Tumor necrosis factor-related } \\
\text { apoptosis-inducing ligand }\end{array}$ \\
\hline Trp-P-2: & $\begin{array}{l}\text { 3-Amino-l-methyl-5H-pyrido }[4,3 \text { - } \\
\text { b]indole }\end{array}$ \\
\hline UV: & Ultraviolet light. \\
\hline
\end{tabular}

\section{Competing Interests}

The authors declare no conflict of interests.

\section{Acknowledgments}

The authors are grateful to the Conselho Nacional de Desenvolvimento Científico e Tecnológico (CNPq) and the Coordenação de Aperfeiçoamento de Pessoal de Nível Superior (CAPES) by financial support.

\section{References}

[1] G. Waris and H. Ahsan, "Reactive oxygen species: role in the development of cancer and various chronic conditions," Journal of Carcinogenesis, vol. 5, article 14, 2006.

[2] M. V. Sobral, A. L. Xavier, T. C. Lima, and D. P. De Sousa, "Antitumor activity of monoterpenes found in essential oils," The Scientific World Journal, vol. 2014, Article ID 953451, 35 pages, 2014.

[3] A. A. Carvalho, L. N. Andrade, É. B. V. de Sousa, and D. P. de Sousa, "Antitumor phenylpropanoids found in essential oils," BioMed Research International, vol. 2015, Article ID 392674, 21 pages, 2015.

[4] L. N. Andrade, T. C. Lima, R. G. Amaral et al., "Evaluation of the cytotoxicity of structurally correlated $p$-menthane derivatives," Molecules, vol. 20, no. 7, pp. 13264-13280, 2015.

[5] D. P. de Sousa, Bioactive Essential Oils and Cancer, Springer International, New York, NY, USA, 1st edition, 2015.

[6] V. Georgiev, A. Ananga, and V. Tsolova, "Recent advances and uses of grape flavonoids as nutraceuticals," Nutrients, vol. 6, no. 1, pp. 391-415, 2014.

[7] C. Kandaswami, L. T. Lee, P. P. Lee et al., "The antitumor activities of flavonoids," In Vivo, vol. 19, pp. 895-909, 2005.

[8] H. Priefert, J. Rabenhorst, and A. Steinbüchel, "Biotechnological production of vanillin," Applied Microbiology and Biotechnology, vol. 56, no. 3-4, pp. 296-314, 2001.

[9] G. S. Clark, "Vanillin: perfume," Flavour, vol. 15, pp. 45-54, 1990. 
[10] N. A. Zamzuri and S. Abd-Aziz, "Biovanillin from agro wastes as an alternative food flavour," Journal of the Science of Food and Agriculture, vol. 93, no. 3, pp. 429-438, 2013.

[11] L. S. Pedroso, G. M. Fávero, L. E. A. De Camargo, R. M. Mainardes, and N. M. Khalil, "Effect of the o-methyl catechols apocynin, curcumin and vanillin on the cytotoxicity activity of tamoxifen," Journal of Enzyme Inhibition and Medicinal Chemistry, vol. 28, no. 4, pp. 734-740, 2013.

[12] A. Tai, T. Sawano, F. Yazama, and H. Ito, "Evaluation of antioxidant activity of vanillin by using multiple antioxidant assays," Biochimica et Biophysica Acta-General Subjects, vol. 1810, no. 2, pp. 170-177, 2011.

[13] T. Sawa, M. Nakao, T. Akaike, K. Ono, and H. Maeda, "Alkylperoxyl radical-scavenging activity of various flavonoids and other phenolic compounds: implications for the anti-tumorpromoter effect of vegetables," Journal of Agricultural and Food Chemistry, vol. 47, no. 2, pp. 397-402, 1999.

[14] B. N. Ames and M. K. Shigenaga, "DNA damage by endogenous oxidants and mitogenesis as causes of aging and cancer," in Molecular Biology of Free Radical Scavengers System, J. G. Scandalios, Ed., pp. 1-22, Cold Spring Harbor Laboratory Press, Plain-View, NY, USA, 1993.

[15] B. N. Ames and L. S. Gold, "Chemical carcinogenesis: too many rodent carcinogens," Proceedings of the National Academy of Sciences of the United States of America, vol. 87, no. 19, pp. 77727776, 1990.

[16] S. Ahmad, Oxidative Stress and Antioxidant Defenses in Biology, Chapman \& Hall, New York, NY, USA, 1995.

[17] Z. Yan-Chun and Z. Rong-Liang, "Phenolic compounds and an analog as superoxide anion scavengers and anti oxidants," Biochemical Pharmacology, vol. 42, no. 6, pp. 1177-1179, 1991.

[18] M. Deters, H. Knochenwefel, D. Lindhorst et al., "Different curcuminoids inhibit T-lymphocyte proliferation independently of their radical scavenging activities," Pharmaceutical Research, vol. 25, no. 8, pp. 1822-1827, 2008.

[19] B. N. Shyamala, M. Madhava Naidu, G. Sulochanamma, and P. Srinivas, "Studies on the antioxidant activities of natural vanilla extract and its constituent compounds through in vitro models," Journal of Agricultural and Food Chemistry, vol. 55, no. 19, pp. 7738-7743, 2007.

[20] A. Rosa, M. Deiana, G. Corona et al., "Protective effect of capsinoid on lipid peroxidation in rat tissues induced by $\mathrm{Fe}-$ NTA," Free Radical Research, vol. 39, no. 11, pp. 1155-1162, 2005.

[21] J. P. Kamat, A. Ghosh, and T. P. A. Devasagayam, "Vanillin as an antioxidant in rat liver mitochondria: inhibition of protein oxidation and lipid peroxidation induced by photosensitization," Molecular and Cellular Biochemistry, vol. 209, no. 1-2, pp. 47-53, 2000.

[22] R. Harish, S. Divakar, A. Srivastava, and T. Shivanandappa, "Isolation of antioxidant compounds from the methanolic extract of the roots of Decalepis hamiltonii (Wight and Arn.)," Journal of Agricultural and Food Chemistry, vol. 53, no. 20, pp. 7709-7714, 2005.

[23] D. K. Maurya, S. Adhikari, C. K. K. Nair, and T. P. A. Devasagayam, "DNA protective properties of vanillin against $\gamma$-radiation under different conditions: possible mechanisms," Mutation Research, vol. 634, no. 1-2, pp. 69-80, 2007.

[24] C. Dhanalakshmi, T. Manivasagam, J. Nataraj, A. J. Thenmozhi, and M. M. Essa, "Neurosupportive role of vanillin, a natural phenolic compound, on rotenone induced neurotoxicity in $\mathrm{SH}$ SY5Y neuroblastoma cells," Evidence-Based Complementary and Alternative Medicine, vol. 2015, Article ID 626028, 11 pages, 2015.

[25] M. Makni, Y. Chtourou, H. Fetoui, E. M. Garoui, T. Boudawara, and N. Zeghal, "Evaluation of the antioxidant, anti-inflammatory and hepatoprotective properties of vanillin in carbon tetrachloride-treated rats," European Journal of Pharmacology, vol. 668, no. 1-2, pp. 133-139, 2011.

[26] H. Ben Saad, D. Driss, S. Ellouz Chaabouni et al., "Vanillin mitigates potassium bromate-induced molecular, biochemical and histopathological changes in the kidney of adult mice," Chemico-Biological Interactions, vol. 252, pp. 102-113, 2016.

[27] L. R. G. Castor, K. A. Locatelli, and V. F. Ximenes, "Pro-oxidant activity of apocynin radical," Free Radical Biology and Medicine, vol. 48, no. 12, pp. 1636-1643, 2010.

[28] K. C. Machado, G. L. S. Oliveira, É. B. V. de Sousa et al., "Spectroscopic studies on the in vitro antioxidant capacity of isopentyl ferulate," Chemico-Biological Interactions, vol. 225, pp. 47-53, 2015.

[29] B. Dimitrios, "Sources of natural phenolic antioxidants," Trends in Food Science and Technology, vol. 17, no. 9, pp. 505-512, 2006.

[30] R. Harish, S. Divakar, A. Srivastava, and T. Shivanandappa, "Isolation of antioxidant compounds from the methanolic extract of the roots of Decalepis hamiltonii (Wight and Arn.)," Journal of Agricultural and Food Chemistry, vol. 53, no. 20, pp. 7709-7714, 2005.

[31] T. Kada and K. Shimoi, "Desmutagens and bio-antimutagenstheir modes of action," BioEssays, vol. 7, no. 3, pp. 113-116, 1987.

[32] T. Ohta, M. Watanabe, K. Watanabe, Y. Shirasu, and T. Kada, "Inhibitory effects of flavourings on mutagenesis induced by chemicals in bacteria," Food and Chemical Toxicology, vol. 24, no. 1, pp. 51-54, 1986.

[33] T. Ohta, M. Watanabe, Y. Shirasu, and T. Inoue, "Post-replication repair and recombination in $u v r A u m u C$ strains of Escherichia coli are enhanced by vanillin, an antimutagenic compound," Mutation Research, vol. 201, no. 1, pp. 107-112, 1988.

[34] K. Takahashi, M. Sekiguchi, and Y. Kawazoe, "Effects of vanillin and o-vanillin on induction of DNA-repair networks: modulation of mutagenesis in Escherichia coli," Mutation Research/ Fundamental and Molecular Mechanisms of Mutagenesis, vol. 230, no. 2, pp. 127-134, 1990.

[35] D. T. Shaughnessy, R. W. Setzer, and D. M. DeMarini, "The antimutagenic effect of vanillin and cinnamaldehyde on spontaneous mutation in Salmonella TA104 is due to a reduction in mutations at GC but not AT sites," Mutation Research/Fundamental and Molecular Mechanisms of Mutagenesis, vol. 480-481, pp. 55-69, 2001.

[36] S. De Flora, C. Bennicelli, A. Rovida, L. Scatolini, and A. Camoirano, "Inhibition of the 'spontaneous' mutagenicity in Salmonella typhimurium TA102 and TA104," Mutation Research/ Fundamental and Molecular Mechanisms of Mutagenesis, vol. 307, no. 1, pp. 157-167, 1994.

[37] D. T. Shaughnessy, R. M. Schaaper, D. M. Umbach, and D. M. DeMarini, "Inhibition of spontaneous mutagenesis by vanillin and cinnamaldehyde in Escherichia coli: dependence on recombinational repair," Mutation Research, vol. 602, no. 1-2, pp. 5464, 2006.

[38] H. H. R. de Andrade, J. H. Santos, M. C. Gimmler-Luz, M. J. F. Correa, M. Lehmann, and M. L. Reguly, "Suppressing effect of vanillin on chromosome aberrations that occur spontaneously or are induced by mitomycin C in the germ cell line of Drosophila melanogaster," Mutation Research, vol. 279, no. 4, pp. 281287, 1992. 
[39] J. H. Santos, U. Graf, M. L. Reguly, and H. H. Rodrigues De Andrade, "The synergistic effects of vanillin on recombination predominate over its antimutagenic action in relation to MMCinduced lesions in somatic cells of Drosophila melanogaster," Mutation Research/Genetic Toxicology and Environmental Mutagenesis, vol. 444, no. 2, pp. 355-365, 1999.

[40] M. Sinigaglia, M. L. Reguly, and H. H. Rodrigues De Andrade, "Effect of vanillin on toxicant-induced mutation and mitotic recombination in proliferating somatic cells of Drosophila melanogaster," Environmental and Molecular Mutagenesis, vol. 44, no. 5, pp. 394-400, 2004.

[41] M. Sinigaglia, M. Lehmann, P. Baumgardt et al., "Vanillin as a modulator agent in SMART test: inhibition in the steps that precede $N$-methyl- $N$-nitrosourea-, $N$-ethyl- $N$-nitrosourea-, ethylmethanesulphonate- and bleomycin-genotoxicity," Mutation Research/Genetic Toxicology and Environmental Mutagenesis, vol. 607, no. 2, pp. 225-230, 2006.

[42] M. P. Furlanetto, M. Sinigaglia, V. S. Do Amaral, R. R. Dihl, and H. H. R. De Andrade, "Effect of vanillin on toxicant-induced lethality in the Drosophila melanogaster DNA repair test," Environmental and Molecular Mutagenesis, vol. 48, no. 1, pp. 6770, 2007.

[43] Y. F. Sasaki, H. Imanishi, T. Ohta, and Y. Shirasu, "Effects of antimutagenic flavourings on SCEs induced by chemical mutagens in cultured Chinese hamster cells," Mutation Research/Genetic Toxicology, vol. 189, no. 3, pp. 313-318, 1987.

[44] Y. Sasaki, H. Imanishi, T. Ohta, and Y. Shirasu, "Effects of vanillin on sister-chromatid exchanges and chromosome aberrations induced by mitomycin $\mathrm{C}$ in cultured Chinese hamster ovary cells," Mutation Research Letters, vol. 191, no. 3-4, pp. 193200, 1987.

[45] Y. Sasaki, H. Imanishi, M. Watanabe, T. Ohta, and Y. Shirasu, "Suppressing effect of antimutagenic flavorings on chromosome aberrations induced by UV-light or X-rays in cultured Chinese hamster cells," Mutation Research, vol. 229, no. 1, pp. 1-10, 1990.

[46] H. Imanishi, Y. Sasaki, K. Matsumoto et al., "Suppression of 6-TG-resistant mutations in V79 cells and recessive spot formations in mice by vanillin," Mutation Research Letters, vol. 243, no. 2, pp. 151-158, 1990.

[47] K. Tamai, H. Tezuka, and Y. Kuroda, "Different modifications by vanillin in cytotoxicity and genetic changes induced by EMS and $\mathrm{H}_{2} \mathrm{O}_{2}$ in cultured Chinese hamster cells," Mutation Research, vol. 268, no. 2, pp. 231-237, 1992.

[48] C. Keshava, N. Keshava, W. Z. Whong, J. Nath, and T. M. Ong, "Inhibition of methotrexate-induced chromosomal damage by vanillin and chlorophyllin in V79 cells," Teratogenesis, Carcinogenesis and Mutagenesis, vol. 17, pp. 313-326, 1997-1998.

[49] C. Keshava, N. Keshava, T.-M. Ong, and J. Nath, "Protective effect of vanillin on radiation-induced micronuclei and chromosomal aberrations in V79 cells," Mutation Research, vol. 397, no. 2, pp. 149-159, 1998.

[50] T. Inouye, Y. F. Sasaki, H. Imanishi, M. Watanabe, T. Ohta, and Y. Shirasu, "Suppression of mitomycin C-induced micronuclei in mouse bone marrow cells by post-treatment with vanillin," Mutation Research, vol. 202, no. 1, pp. 93-95, 1988.

[51] Y. Sasaki, T. Ohta, H. Imanishi et al., "Suppressing effects of vanillin, cinnamaldehyde, and anisaldehyde on chromosome aberrations induced by X-rays in mice," Mutation Research Letters, vol. 243, no. 4, pp. 299-302, 1990.
[52] S. S. Kumar, A. Ghosh, T. P. A. Devasagayam, and P. S. Chauhan, "Effect of vanillin on methylene blue plus light-induced singlestrand breaks in plasmid pBR322 DNA," Mutation Research, vol. 469, no. 2, pp. 207-214, 2000.

[53] D. L. Gustafson, H. R. Franz, A. M. Ueno, C. J. Smith, D. J. Doolittle, and C. A. Waldren, "Vanillin (3-methoxy-4-hydroxybenzaldehyde) inhibits mutation induced by hydrogen peroxide, $\mathrm{N}$-methyl-N-nitrosoguanidine and mitomycin $\mathrm{C}$ but not ${ }^{137} \mathrm{Cs}-\gamma$-radiation at the CD59 locus in human-hamster hybrid $\mathrm{A}_{L}$ cells," Mutagenesis, vol. 15, no. 3, pp. 207-213, 2000.

[54] S. Durant and P. Karran, "Vanillins-a novel family of DNA-PK inhibitors," Nucleic Acids Research, vol. 31, no. 19, pp. 5501-5512, 2003.

[55] R. Sanyal, F. Darroudi, W. Parzefall, M. Nagao, and S. Knasmüller, "Inhibition of the genotoxic effects of heterocyclic amines in human derived hepatoma cells by dietary bioantimutagens," Mutagenesis, vol. 12, no. 4, pp. 297-303, 1997.

[56] A. A. King, D. T. Shaughnessy, K. Mure et al., "Antimutagenicity of cinnamaldehyde and vanillin in human cells: global gene expression and possible role of DNA damage and repair," Mutation Research/Fundamental and Molecular Mechanisms of Mutagenesis, vol. 616, no. 1-2, pp. 60-69, 2007.

[57] J. Lee, J. Y. Cho, S. Y. Lee, K.-W. Lee, J. Lee, and J.-Y. Song, "Vanillin protects human keratinocyte stem cells against Ultraviolet B irradiation," Food and Chemical Toxicology, vol. 63, pp. 30-37, 2014.

[58] H. Ben Saad, I. Ben Amara, N. Krayem et al., "Ameliorative effects of vanillin on potassium bromate induces bone and blood disorders in vivo," Cellular and Molecular Biology, vol. 61, pp. 12-22, 2015.

[59] H. Ben Saad, D. Driss, I. Ben Amara et al., "Altered hepatic mRNA expression of immune response-associated DNA damage in mice liver induced by potassium bromate: protective role of vanillin," Environmental Toxicology, vol. 31, no. 12, pp. 17961807, 2016.

[60] H. Tsuda, N. Uehara, Y. Iwahori et al., "Chemopreventive effects of $\beta$-carotene, $\alpha$-tocopherol and five naturally occurring antioxidants on initiation of hepatocarcinogenesis by 2-amino-3methylimidazo[4,5- $f$ ]quinoline in the rat," Japanese Journal of Cancer Research, vol. 85, no. 12, pp. 1214-1219, 1994.

[61] K. Akagi, M. Hirose, T. Hoshiya, Y. Mizoguchi, N. Ito, and T. Shirai, "Modulating effects of ellagic acid, vanillin and quercetin in a rat medium term multi-organ carcinogenesis model," Cancer Letters, vol. 94, no. 1, pp. 113-121, 1995.

[62] K. L. Ho, P. P. Chong, L. S. Yazan, and M. Ismail, "Vanillin differentially affects azoxymethane-injected rat colon carcinogenesis and gene expression," Journal of Medicinal Food, vol. 15, no. 12, pp. 1096-1102, 2012.

[63] S. Kapoor, "Multiorgan anticarcinogenic effects of vanillin," Journal of Medicinal Food, vol. 16, no. 9, pp. 777-777, 2013.

[64] K. Lirdprapamongkol, H. Sakurai, N. Kawasaki et al., "Vanillin suppresses in vitro invasion and in vivo metastasis of mouse breast cancer cells," European Journal of Pharmaceutical Sciences, vol. 25, no. 1, pp. 57-65, 2005.

[65] J.-A. Liang, S.-L. Wu, H.-Y. Lo, C.-Y. Hsiang, and T.-Y. Ho, "Vanillin inhibits matrix metalloproteinase-9 expression through down-regulation of nuclear factor- $\kappa \mathrm{B}$ signaling pathway in human hepatocellular carcinoma cells," Molecular Pharmacology, vol. 75, no. 1, pp. 151-157, 2009.

[66] K. Lirdprapamongkol, J.-P. Kramb, T. Suthiphongchai et al., "Vanillin suppresses metastatic potential of human cancer cells 
through PI3K inhibition and decreases angiogenesis in vivo," Journal of Agricultural and Food Chemistry, vol. 57, no. 8, pp. 3055-3063, 2009.

[67] H. Babich, E. Borenfreund, and A. Stern, "Comparative cytotoxicities of selected minor dietary non-nutrients with chemopreventive properties," Cancer Letters, vol. 73, no. 2-3, pp. 127-133, 1993.

[68] K. Ho, L. S. Yazan, N. Ismail, and M. Ismail, "Apoptosis and cell cycle arrest of human colorectal cancer cell line HT-29 induced by vanillin," Cancer Epidemiology, vol. 33, no. 2, pp. 155-160, 2009.

[69] W.-Y. Cheng, C.-Y. Hsiang, D.-T. Bau et al., "Microarray analysis of vanillin-regulated gene expression profile in human hepatocarcinoma cells," Pharmacological Research, vol. 56, no. 6, pp. 474-482, 2007.

[70] K. Lirdprapamongkol, H. Sakurai, S. Suzuki et al., "Vanillin enhances TRAIL-induced apoptosis in cancer cells through inhibition of NF-kappaB activation," In Vivo, vol. 24, no. 4, pp. 501-506, 2010.

[71] J. Deb, H. Dibra, S. Shan et al., "Activity of aspirin analogues and vanillin in a human colorectal cancer cell line," Oncology Reports, vol. 26, no. 3, pp. 557-565, 2011. 


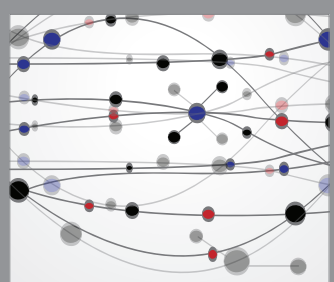

The Scientific World Journal
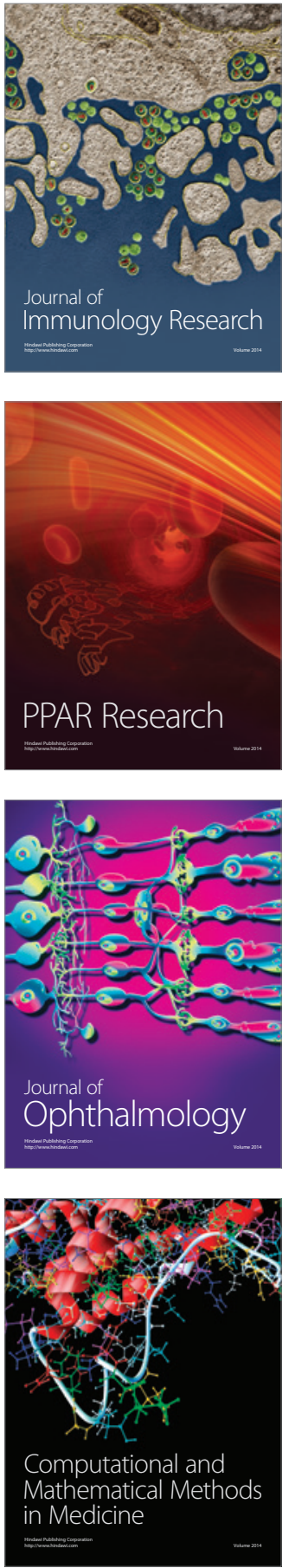

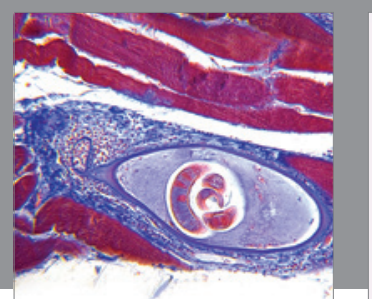

Gastroenterology Research and Practice

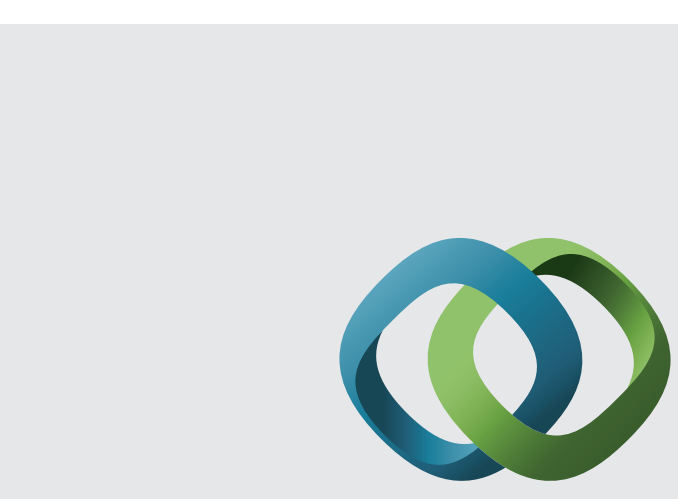

\section{Hindawi}

Submit your manuscripts at

http://www.hindawi.com
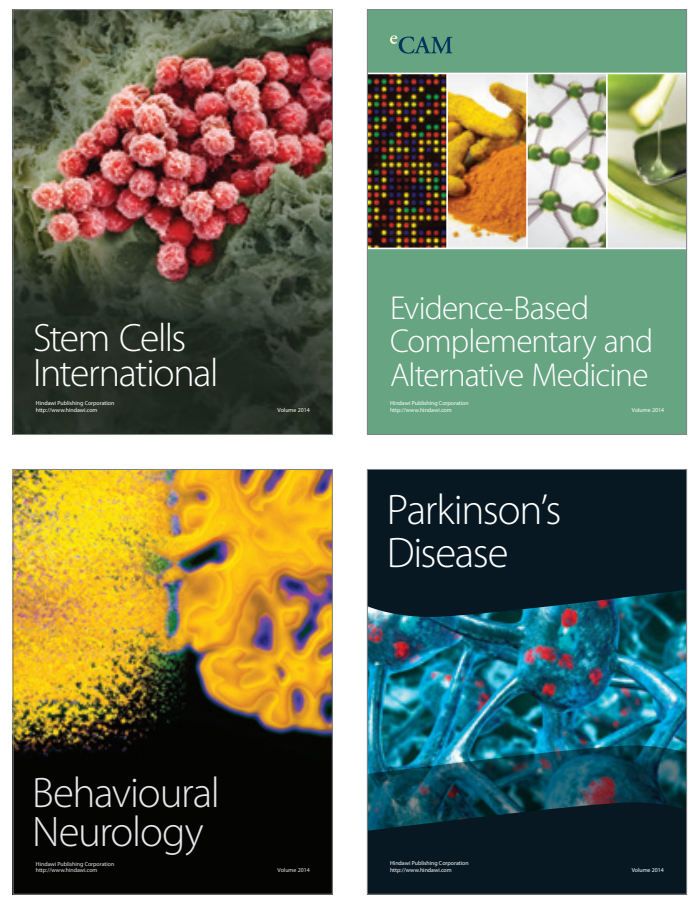
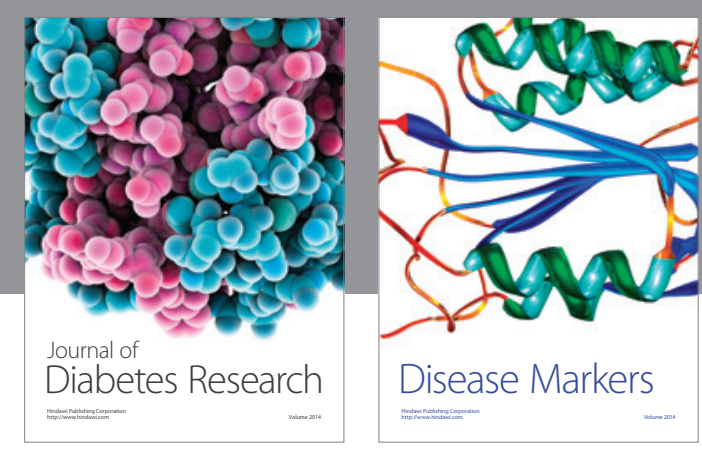

Disease Markers
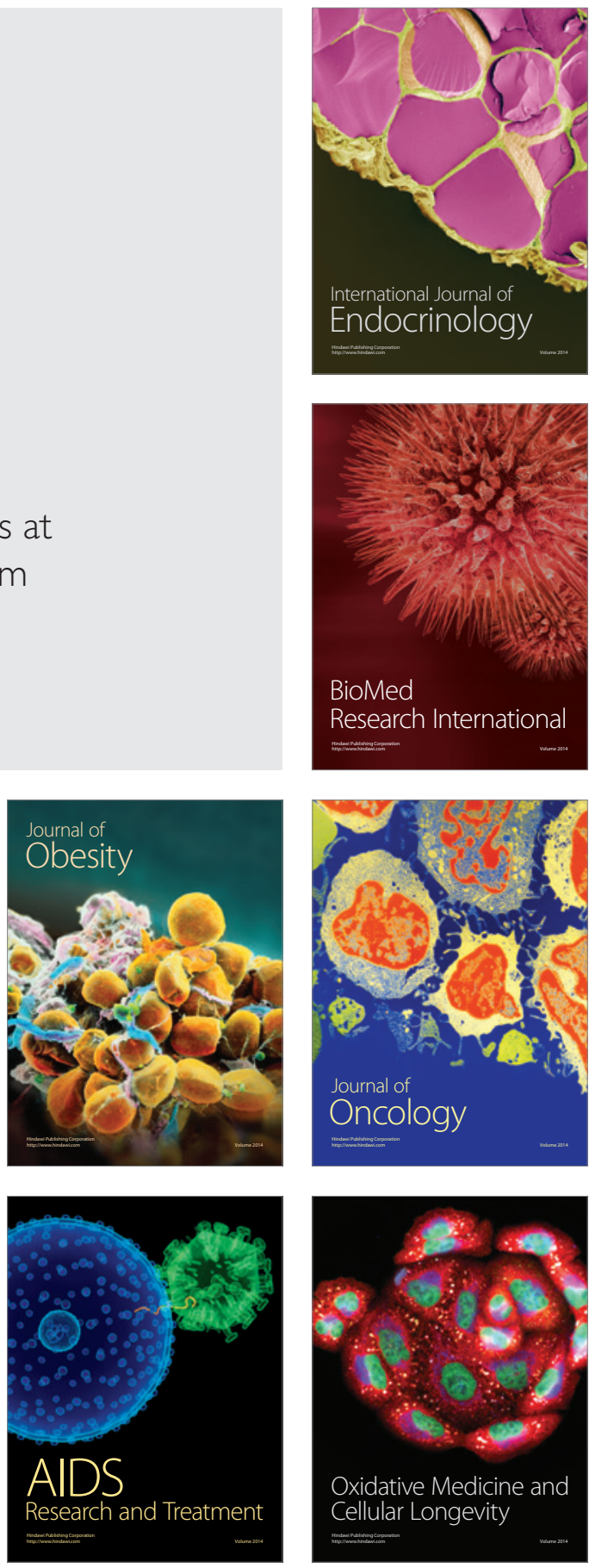